\title{
Stromal cell derived factor-1alpha protects stem cell derived insulin-producing cells from glucotoxicity under high glucose conditions in-vitro and ameliorates drug induced diabetes in rats
}

\author{
Muhammad Tariq ${ }^{1,2^{*}}$, Muhammad Sharif Masoud ${ }^{1,3}$, Azra Mehmood', Shaheen N Khan ${ }^{1}$ and Sheikh Riazuddin ${ }^{1}$
}

\begin{abstract}
Background: Diabetes mellitus is affecting more than 300 million people worldwide. Current treatment strategies cannot prevent secondary complications. Stem cells due to their regenerative power have long been the attractive target for the cell-based therapies. Mesenchymal stem cells (MSCs) possess the ability to differentiate into several cell types and to escape immune recognition in vitro. MSCs can be differentiated into insulin-producing cells (IPCs) and could be an exciting therapy for diabetes but problems like poor engraftment and survivability need to be confronted. It was hypothesized that stromal cell derived factor- 1alpha (SDF-1alpha) will enhance therapeutic potential of stem cell derived IPCs by increasing their survival and proliferation rate.
\end{abstract}

Methods: Novel culture conditions were developed to differentiate bone marrow derived mesenchymal stem cells (BMSCs) into IPCs by using endocrine differentiation inducers and growth factors via a three stage protocol. In order to enhance their therapeutic potential, we preconditioned IPCs with SDF-1alpha.

Results: Our results showed that SDF-1alpha increases survival and proliferation of IPCs and protects them from glucotoxicity under high glucose conditions in vitro. SDF-1alpha also enhances the glucose responsive insulin secretion in IPCs in vitro. SDF-1alpha preconditioning reverses hyperglycemia and increase serum insulin in drug induced diabetic rats.

Conclusions: The differentiation of BMSCs into IPCs and enhancement of their therapeutic potential by SDF-1alpha preconditioning may contribute to cell based therapies for diabetes.

Keywords: Diabetes mellitus, Mesenchymal stem cells, Differentiation, Preconditioning, SDF-1a

\section{Background}

Diabetes mellitus (DM), a life threatening single-cell metabolic disorder, is defined by the presence of hyperglycemia due to damage or faulty pancreatic beta cells. Type 1 diabetes results from T-cell mediated autoimmune demolition of $\beta$-cells [1]. At least 285 million people were affected from diabetes in 2010 worldwide and this number is increasing day by day [2]. The treatment of the absolute insulin deficiency resulting from Type 1 diabetes is very

\footnotetext{
*Correspondence: m_awan_tariq@hotmail.com

'National Centre of Excellence in Molecular Biology, University of the Punjab, Lahore, Pakistan

${ }^{2}$ Current Affiliation: Department of Biotechnology, Mirpur University of Science and Technology, Mirpur, AK, Pakistan

Full list of author information is available at the end of the article
}

challenging. Despite significant advances in the manufacture, modification and delivery of insulin, insulin therapy remains relatively risky and cannot prevent secondary complications. Islet-transplantation, the most successful treatment of DM, is hampered due to issues such as; severe shortage of pancreas donors, low islet isolation success rate, difficulty in maintaining an insulin-free status and the side effects of anti-rejection drugs [3,4]. Thus it is the need of hour to look for new strategies to generate pancreatic beta cells either in vitro or in vivo. An attractive approach for reversing diabetes is beta cell regeneration from adult stem cells. By using beta cells from a patient's own adult stem cells, immunosuppression can be avoided. 
Bone marrow derived mesenchymal stem cells (BMSCs) are able to differentiate into a number of different cell types of mesodermal lineages such as adipocytes, osteoblasts and other mesodermal cells [5,6]. MSCs can be differentiated into insulin producing cells (IPCs) and their possible therapeutic potential for diabetes depends upon this differential ability [7-9]. IPCs express the pancreatic $\beta$-cells developmental genes such as pancreatic and duodenal homeobox-1 (PDX-1) or functional genes such as insulin, and glucagon [8-11] and secrete insulin in response to glucose that reverses hyperglycemia in druginduced diabetic mice $[8,9,12]$. The remedial use of MSCs is limited at present due to several problems such as poor engraftment, limited differentiation in host tissue [13] and differentiation of MSCs into unwanted lineages [14] by a variety of factors [15].

The enhancement of survival and proliferation of MSCs by growth factors has been extensively studied. The majority of growth factors is pleiotropic and changes motility, proliferation, morphogenesis and survival of cells. Glucose homeostasis is regulated by several polypeptides such as insulin, adiponectin, glucagon-like peptide-1 (GLP-1), and many others making them attractive candidates for the treatment of diabetes [16]. Many different strategies have been employed to induce the differentiation of IPCs from stem cells in vitro. These strategies have involved supplementation of differentiation medium with a variety of induction and growth factors, such as nourished ES cells with all-trans retinoic acid [17], betacellulin, activin A [18] and vitamin derivatives such as nicotinamide [19]. A number of studies have highlighted the role of GLP-1, a known anti-diabetic agent, in $\beta$ cell development, function, proliferation and neogenesis [20,21]. Stromal cell-derived factor-1 (SDF-1), a chemokine known to express in stromal tissues in multiple organs, promotes $\beta$-cell survival in RIP-SDF- 1 transgenic mice and MIN- 6 and INS-1 clonal beta-cells by the activation of Akt signaling pathway and attenuates diabetes in streptozotocin (STZ) induced mice [22]. The activation of Akt signaling pathway have cell survival, cell proliferating and anti-apoptotic roles. SDF- 1/CXCR4 axis modulates cell migration and cell survival during development and tissue remodeling [23]. Moreover, SDF-1 $\alpha$ /CXCR4 is an obligatory component in the maintenance of pancreatic duct cell-survival, cell-proliferation and migration during pancreatic organogenesis and regeneration in pancreatic acinar cells [24]. The PI3K/Akt pathway is an important mediator of cell survival in many cell types such as beta cells [25-27] and PI3K/Akt signaling has been shown to play a central role in pancreatic regeneration [28]. To make use of the therapeutic potential of SDF- $1 \alpha$ pre-conditioning in IPCs survival and proliferation, we hypothesized that SDF- $1 \alpha$ pre-conditioning augments IPCs survival and may reverse hyperglycemia.

\section{Methods}

\section{Animals care}

The current study was carried according to the Guide for the Care and Use of Laboratory Animals published by the US National Institutes of Health (NIH Publication No. 85-23, revised 1996). All animals were treated according to the procedures approved by the Institutional Review Board (IRB) at the National Center of Excellence in Molecular Biology, Lahore, Pakistan.

\section{Animals}

Inbred Sprague-Dawley (SD) rats, aged 8-16 weeks, were used in this study as streptozotocin can easily cause diabetes in these animals [29]. Rats were placed in a special room where the temperature was kept at $22^{\circ} \mathrm{C}$ and the light was on a $12 \mathrm{hr}$ dark / light cycle throughout the year.

\section{Isolation and culture of rat BM-derived MSCs}

Rat BMSCs were isolated and cultured as previously described [30]. In brief, bone marrow was isolated from the femur and tibia of 3-4 months old SD rats. After removing epiphyses and gaining access to the marrow cavities, whole BM was flushed out from bones. The resulting cell suspension was centrifuged and the cell pellet was re-suspended in DMEM-LG supplemented with $10 \%$ fetal bovine serum (FBS) and 1\% antibiotic (100 $\mathrm{\mu g} / \mathrm{ml}$ streptomycin and $100 \mathrm{U} / \mathrm{ml}$ penicillin). The cells were plated in tissue culture flask and placed in incubator having $5 \% \mathrm{CO}_{2}$ and $95 \%$ air at $37^{\circ} \mathrm{C}$. The medium was then changed after every three days. When cells were $80 \%$ confluent, they were sub-cultured in a ratio $1: 3$.

\section{Differentiation of BMSCs into IPCs}

When BMSCs at 3rd passage were 70\%-80\% confluent, they were differentiated into insulin producing cells (IPCs) by a three stage protocol as follows. Stage 1: The cells were induced with DMEM-LG containing $0.5 \mathrm{mM} / \mathrm{L} 2$ mercaptoethanol, $10 \mathrm{mM} / \mathrm{L}$ nicotinamide and 5\% FBS for 2 days. Stage 2: The pre-induced cells were further treated with serum free DMEM high glucose (DMEMHG) medium containing $0.5 \mathrm{mM} / \mathrm{L} 2$-mercaptoethanol, $10 \mathrm{mM} / \mathrm{L}$ nicotinamide and $10 \mathrm{ng} / \mathrm{ml}$ activin A for 10 hours. Stage 3: The cells were cultured for an additional 8 days in new DMEM-HG medium containing $20 \mathrm{ng} / \mathrm{ml}$ $\beta$-fibroblast growth factor (bFGF, Sigma), $20 \mathrm{ng} / \mathrm{ml}$ epidermal growth factor (EGF, Sigma), 2\% B27 (Gibco), 2 mM/L L-glutamine (Hyclone Laboratories), $10 \mathrm{mM} / \mathrm{L}$ nicotinamide and $50 \mathrm{ng} / \mathrm{ml}$ GLP-1.

\section{Identification of IPCs by dithizone (DTZ) staining}

Presence of IPCs in culture can be identified with $\mathrm{Zn}$ chelating agent dithizone which binds with free $\mathrm{Zn}^{2+}$ present in these cells. The stock solution was prepared 
by dissolving $50 \mathrm{mg}$ of DTZ (Merck) in $5 \mathrm{ml}$ DMSO and stored at $-20^{\circ} \mathrm{C}$ until used. The working solution of DTZ was prepared by bringing stock solution to room temperature. $10 \mu \mathrm{l}$ working DTZ solution was added to culture medium and incubated for $30 \mathrm{~min}$ at $37^{\circ} \mathrm{C}$. The crimson-red-stained clusters were observed under a microscope.

\section{Immunocytochemical analysis for pancreatic developmental markers in IPCs}

To confirm the differentiation of BMSCs into IPCs, cultured IPCs were incubated with primary antibodies specific to insulin, $\mathrm{Ngn} 3$ and $\mathrm{Pdx}-1$ and then treated to respective secondary antibodies. Nuclei were counterstained with DAPI. At least six randomly high power fields were selected from each slide. Fluorescent images were obtained with an Olympus IX 51 and BX 61 microscopes equipped with digital cameras (Olympus).

\section{RT-PCR analysis for expression of genes of pancreatic development in IPCs}

Total cellular RNA was extracted from BMSCs, IPCs and pancreatic tissue by using TRIZOL reagent (Invitrogen). cDNA was synthesized using total RNA by Revert Aid H Minus first strand cDNA synthesis kit (Fermentas; Cat\# K1632). Following PCR conditions were used: 1 cycle at $94^{\circ} \mathrm{C}$ for $4 \mathrm{~min}: 35$ cycles at $\left(94^{\circ} \mathrm{C}\right.$ for $45 \mathrm{~s}$, annealing temp for $45 \mathrm{~s}$ and $72^{\circ} \mathrm{C}$ for $60 \mathrm{~s}$ ) and 1 extended cycle at $72^{\circ} \mathrm{C}$ for $10 \mathrm{~min}$. The PCR products were size-fractionated by $2.0 \%$ agarose gel electrophoresis. The oligonucleotide sequences specific for the selected genes are presented in Table 1.

\section{Preconditioning of IPCs}

At day 11, BMSCs derived IPCs were preconditioned with SDF-1 $\alpha$. IPCs were incubated in normal DMEMHG containing $50 \mathrm{ng} / \mathrm{ml} \mathrm{GLP-1,10 \%} \mathrm{FBS} \mathrm{and} 50 \mathrm{ng} / \mathrm{ml}$ SDF- $1 \alpha$ for 48 hours in $\mathrm{CO}_{2}$ incubator and rinsed for 10 min with normal medium for further in vitro and in vivo studies.

\section{In vitro experiments}

Three experimental groups were assigned as follows: (I) Normal BMSCs at 3rd passage; (II) Non-preconditioned IPCs incubated in normal DMEM-HG containing $50 \mathrm{ng} / \mathrm{ml}$ GLP-1 and 10\% FBS; (III) SDF-1 $\alpha$ preconditioned IPCs incubated in normal DMEM-HG containing $50 \mathrm{ng} / \mathrm{ml}$ GLP-1, 10\% FBS and $50 \mathrm{ng} / \mathrm{ml} \mathrm{SDF-1 \alpha .} \mathrm{All} \mathrm{groups} \mathrm{were}$ incubated for 48 hours in $\mathrm{CO}_{2}$ incubator and rinsed for 10 min with normal medium. To compare the effect of different glucose concentrations on above mentioned groups, a total of $2 \times 10^{4}$ cells/well were cultured in 24-well plates in the DMEM containing $5.5 \mathrm{mM} / \mathrm{L}, 17 \mathrm{mM} / \mathrm{L}$ and $33 \mathrm{mM} / \mathrm{L}$ glucose for 2 days.
Table 1 Primer sequences of various genes

\begin{tabular}{lll}
\hline Genes & & \multicolumn{1}{c}{ Primer sequences } \\
\hline Insulin 1 & Forward & 5'-CAGTTGGTAGAGGGAGCAG-3' \\
& Reverse & 5'-CAGTTGGTAGAGGGAGCAG-3' \\
Insulin 2 & Forward & 5'-TCATCCTCTGGGAGCCCCGC-3' \\
& Reverse & 5'-AGTTGCAGTAGTTCTCCAGT-3' \\
Ngn3 & Forward & 5'-CTTCACAAGAAGTCTGAGAACACCAG-3' \\
& Reverse & 5'-CTGCGCATAGCGGACCACAGCTTC-3' \\
Pdx-1 & Forward & 5'-GGTGCCAGAGTCAGTGCTAA-3' \\
& Reverse & 5'-CCAGTCTCGGTTCCATTCG-3' \\
Nkx 6.1 & Forward & 5'-ATGGGAAGAGAAAACACACCAGAC-3' \\
& Reverse & 5'-TAATCGTCGTCGTCCTCCTCGTTC-3' \\
Nkx 6.2 & Forward & 5'-AGAAAGGTATGGAGGTGACG-3' \\
& Reverse & 5'-CTGTACTGGGCGTGTATTG-3' \\
B-Actin & Forward & 5'-GCTGTGTTGTCCTGTATGC-3' \\
& Reverse & 5'-GAGCGCGTAACCCTCATAGA-3' \\
\hline
\end{tabular}

\section{Measurement of lactate dehydrogenase (LDH) and cell viability}

The cell viability was evaluated after treating with different concentrations of glucose by the trypan blue dyeexclusion method. Cell supernatant was analyzed for $\mathrm{LDH}$ activity using LDH based in vitro toxicological kit TOX7 (Sigma) and taking absorbance at $490 \mathrm{~nm}$ and a reference wavelength of $690 \mathrm{~nm}$ to obtain sample signal $\left(\mathrm{OD}_{490}-\mathrm{OD}_{690}\right)$.

\section{Cell proliferation assay}

The cells treated with different glucose concentrations were incubated for 2-3 hrs with $40 \mu \mathrm{l} /$ well MTT (3-(4, 5-Dimethylthiazol-2-yl)-2, 5-diphenyltetrazolium bromide) reagent (Sigma-Aldrich) having concentration of $5 \mathrm{mg} / \mathrm{ml}$. The medium was aspirated and the cells were suspended in dimethyl sulfoxide. Absorbance of the formazan product which is directly proportional to the number of living cells was measured by an ELISA plate reader at $570 \mathrm{~nm}$ and a reference wavelength of $630 \mathrm{~nm}$ to obtain sample signal $\left(\mathrm{OD}_{570}-\mathrm{OD}_{630}\right)$.

\section{ELISA for insulin}

To determine whether SDF- $1 \alpha$ preconditioning causes an increase in insulin release from IPCs, an enzyme-linked immunoassay (ELISA) was used to quantify insulin levels in various groups after incubating with different glucose concentrations for 2 days. Cells were incubated with freshly prepared Krebs Ringer bicarbonate HEPES (KRBH) buffer supplemented with $3.8 \mathrm{mM} / \mathrm{L}$ glucose for $2 \mathrm{hrs}$ at $37^{\circ} \mathrm{C}$. Then $\mathrm{KRBH}$ buffer supplemented with $5.5 \mathrm{mM} / \mathrm{L}$, $17 \mathrm{mM} / \mathrm{L}$ and $33 \mathrm{mM} / \mathrm{L}$ glucose was added to tissue culture plates and incubated for $3 \mathrm{hrs}$ at $37^{\circ} \mathrm{C}$. Supernatant was collected and insulin released was determined by 
ELISA. The absorbance was measured at 490nm and evaluated. The results were compared with a standard curve constructed with murine insulin (each assay carried out in triplicate for each group).

\section{In vivo experiments \\ Induction of diabetes}

Diabetes was induced in 20 female SD rats at 8-16 weeks of age by intraperitoneal injection of $40 \mathrm{mg} / \mathrm{kg}$ of streptozotocin (STZ) in cold sodium citrate buffer $(\mathrm{pH} 4.5)$. Control rats were treated with citrate buffer only. Blood glucose levels were measured by using Roche ACCU-CHEK glucometer. Stable blood glucose levels ranging between $300-520 \mathrm{mg} / \mathrm{dl}$ developed in rats one week later while blood glucose levels of normal rats were in range of $75-125 \mathrm{mg} / \mathrm{dl}$.

\section{PKH26-labelling of cells}

Prior to transplantation in the kidney capsule, IPCs were labeled with PKH26 (Sigma, Product no.: PKH26-GL) according to manufacturer's protocol. This lipophilic dye PKH26 binds irreversibly to the cell membranes and serves an important marker for tracking stem cells in the transplanted tissue.

\section{Transplantation}

Diabetic rats were divided into three groups $(n=12)$ after showing consistent hyperglycemia (blood glucose $>$ $300 \mathrm{mg} / \mathrm{dl}$ ) for at least three measurements. The diabetic rats of 1 st group received IPCs pre-conditioned with SDF-1 $\alpha$, 2nd group received IPCs only and 3rd group was injected with serum free medium. Rats were anesthetized, shaved from left dorsal side and cleaned. A small incision was made on the left flank of the rat and the kidney was exposed. A total of $3 \times 10^{6}$ labeled cells were transplanted into the left kidney capsule at three different sites.

\section{Measurement of blood glucose and serum insulin}

The blood glucose levels were monitored at every third day by using AccuChek glucometer for 30 days after transplantation. The blood samples from transplanted rats were collected at day 7, 14, 21 and 28. Serum was isolated from these samples and insulin was measured by ELISA.

\section{Organ procurement and processing}

Rats were euthanized at 28 days after cell transplantation. For cryo sectioning, the excised kidney and pancreatic tissues were embedded in Tissue-Tek OCT (Sakura Torrance, CA, USA). 5 um thick tissue sections were cut with the help of cryostat (Microm) at $-20 \mathrm{C}^{\circ}$.

\section{Homing of transplanted cells}

To assess the homing of transplanted IPCs, the sections were prepared from frozen tissues. Sections were examined under fluorescent microscope Olympus BX61 using standard filter setup for TRITC (PKH26). The stained sections were digitally imaged using a computerized image-analysis system. The number of $\mathrm{PKH} 26$ positive cells was counted in six randomly selected areas.

\section{Immunohistochemical analysis for Ki-67 for determination of proliferating cells}

The proliferating cells in pancreata of diabetic rats after transplantation were seen by staining with immPRESS Reagent (Vector Labs) using manufacturer's protocol. Briefly, air dried, acetone fixed frozen sections were washed with PBS and incubated for 20 min with 2.5\% normal horse blocking serum. Sections were incubated with primary antibodies specific to $\mathrm{Ki}-67$ and treated with ImmPRESS reagent. Sections were incubated in peroxidase substrate solution until sufficient stain developed. Nuclei were counter-stained with eosin. At least six randomly high power fields were selected from each slide. Fluorescent images were obtained with an Olympus BX61 microscope equipped with digital cameras (Olympus).

\section{Statistical analysis}

Experiments were performed in quadruplicate and repeated at least three times. All values are expressed as mean \pm standard error of the mean (SEM). Statistical significance was analyzed using one way ANOVA followed by Bonferroni testing through Graphpad Prism 5 software. A $p$-value $\leq 0.05$ was considered statistically significant.

\section{Results and discussion In vitro study}

\section{Differentiation of BMSCs into beta like IPCs}

At day 5 of induction, BMSCs started to form sphereshaped clusters which attained their maximum size and maximal number at day 11 while control BMSCs which were not induced did not show any cluster formation (Figure 1a). Many cells in the culture induced with different reagents and growth factors stained crimson red with DTZ (Figure 1b) indicating the differentiation of BMSCs into IPCs. Control BMSCs were not stained. The culture induced with different reagents and growth factors expressed transcripts of insulin-I and insulin-II along with transcription factors Pdx-1, Ngn3, Nkx 6.1 and Nkx 6.2 (Figure 2b) at the completion of treatment. Immunostaining of induced cultured cells showed many insulin positive cells (Figure 2a) while the nuclei of differentiated IPCs expressed transcription factors Ngn3 and PDX-1 (Figure 2a). Treatment of BMSCs with insulin-promoting factors such as nicotinamide, high 
glucose induction and growth factors such as activin $\mathrm{A}$ and GLP-1 differentiate them into IPCs. Nicotinamide, a poly(ADP-ribose) synthetase inhibitor, is a well-known inducer to differentiate stem cells into IPCs and protect cells from glucotoxicity induced by exposure to high glucose [9,12,19,31]. Tang et al., (2004) considered high glucose concentration as a potent inducer for pancreatic islet differentiation [32]. But Sun et al., (2007) reported that high glucose alone could not induce bone marrowderived MSCs to IPCs [9]. Activin A, a member of the transforming growth factor-beta (TGF- $\beta$ ) super-family, regulated neogenesis of $\beta$-cells in vivo [33] and induced ESCs into pancreatic $\beta$-cells [18]. GLP-1, an incretin hormone, used to convert intestinal epithelial cells into IPCs [34] and also differentiated BMSCs into IPCs [35]. Neshati et al., (2010) indicated that treatment of MSCs with high glucose, nicotinamide and 2-mercaptoethanol differentiated them into IPCs [36]. In the present study, we combined the previously used endocrine differentiation inducers in a novel way to differentiate BMSCs into IPCs.

The pancreas develops under a cascade of gene activation events controlled by transcription factors including PDX-1, Ngn3, NeuroD1, PAX-6, PAX-4, Nkx2.2, Nkx6.1 and so on $[37,38]$. Nkx-6.1 is exclusively expressed in the islets of Langerhans in differentiating and mature beta-cells. The presence of PDX-1 is required for the expression of Nkx-6.1 as well as other pancreatic beta cell specific genes, including insulin and both $\mathrm{Nkx} 6.1$ and Nkx 6.2 activity is required for $\alpha$ - and beta-cell development in the pancreas [39]. Nkx 6.1 regulates the expression of Nkx 6.2 [39]. Therefore, in vitro differentiated IPCs should express genes of the pancreatic developmental transcription factors mentioned above along with the genes for insulin I and insulin II.

In this study, the expression of PDX1 observed at day 3 (Figure 2b) may have initiated a cascade of events that leads towards insulin transcription as PDX-1 controls the transcription of endocrine progenitor cells. PDX-1 contributes to specification of endocrine progenitors both by regulating expression of Ngn3 directly and by participating in a cross-regulatory transcription factor network during early pancreas development [40]. Following PDX-1 gene activation, the pancreatic transcriptional activation of genes such as Ngn3 occurs [41,42]. In our study, Ngn3 stably expressed at day 11 (Figure 2b). Ngn3 is required for the development of the four endocrine cell lineages (alpha, beta, delta and PP) of the pancreas [43]. In our study both Nkx 6.1 and Nkx 6.2 were expressed during the differentiation of BMSCs into IPCs. The expression of the transcripts of the major pancreatic hormones insulin1 and insulin-2 further confirmed the differentiation of

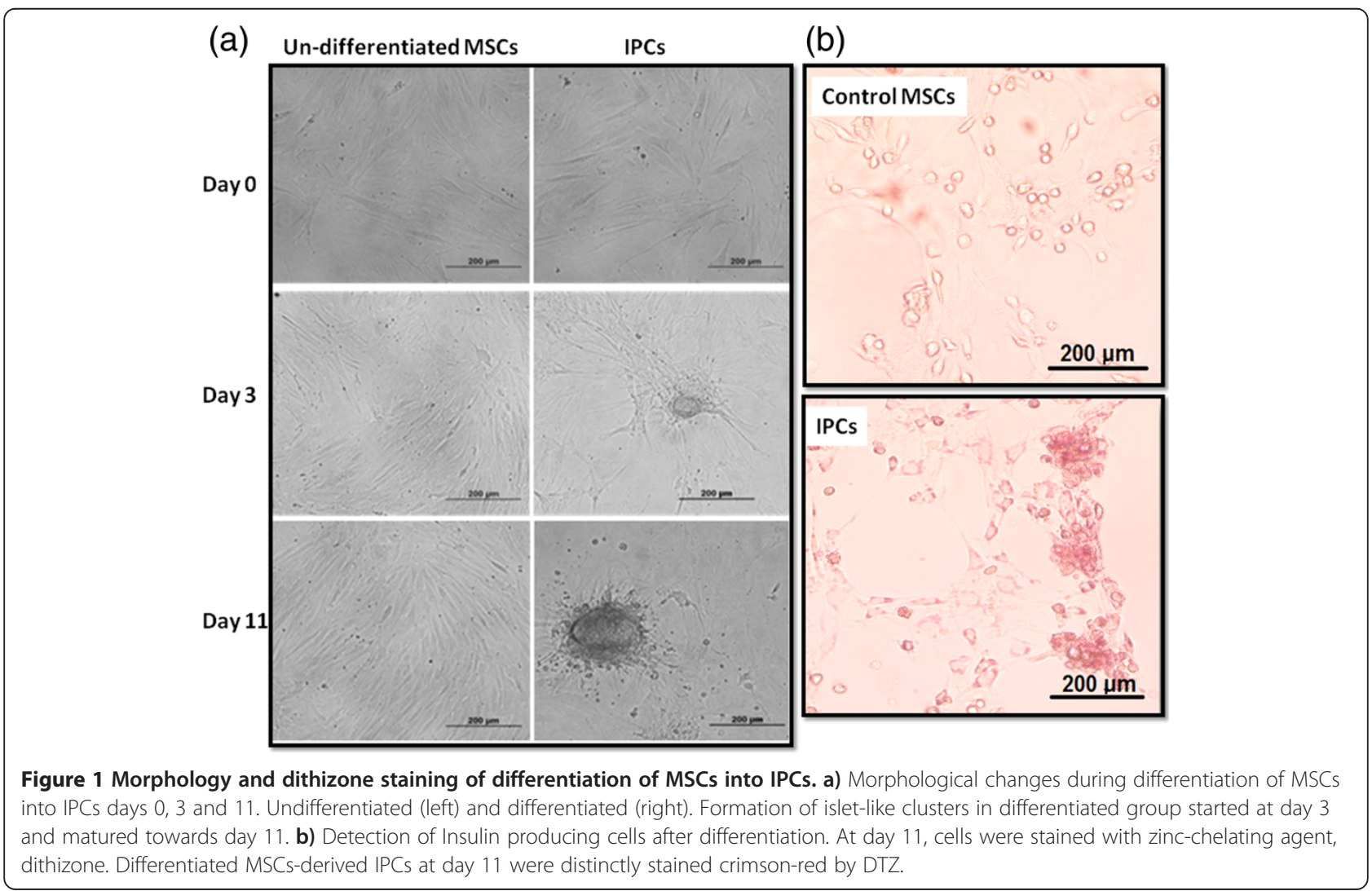



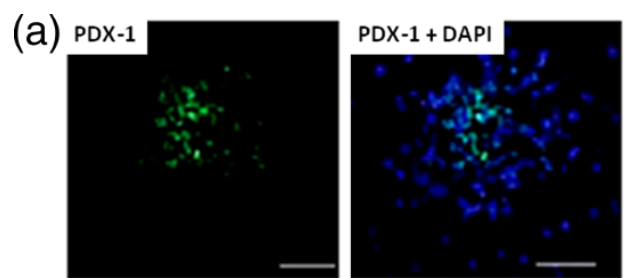

(b)
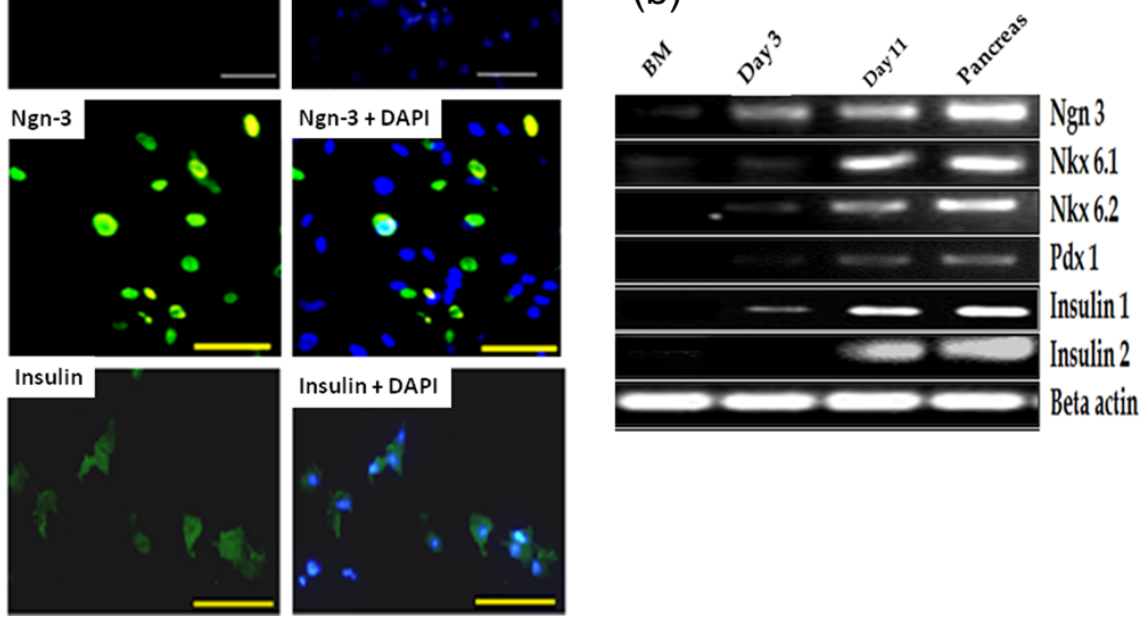

Figure 2 Expression of pancreas specific hormones and transcription factors in differentiated IPCs at day 11. a) Immunofluorescence analysis in differentiated IPCs at day11 of Pdx-1 (10X), Ngn3 (20X) and Insulin (20X). b) Reverse transcriptase analysis. Lane 1) BM-derived MSCs at passage-3 before the start of treatment at day 0 Lane 2) BM-derived MSCs after pre-induction after stage-2 at day 3 Lane 3) Differentiated BMderived MSCs after stage-3 at day 11 Lane 4) Pancreas as positive control.

IPCs. The gene expression pattern observed during differentiation (Figure 2b) was similar to that of pancreatic tissue.

\section{SDF-1a preconditioning enhances cell viability and} proliferation of IPCs under high glucose conditions This study demonstrated for the first time the effect of SDF- $1 \alpha$ pre-conditioning on IPCs in vitro as well as in vivo. Differentiated IPCs were pre-conditioned with SDF-1 $\alpha$. Cell viability evaluated by trypan blue exclusion assay showed marked increase in viable cells in SDF- $1 \alpha$ preconditioned group compared with the control and non-preconditioned group (Figure 3a). To assess cell proliferation in the differentiated IPCs after pre-conditioning with SDF- $1 \alpha$, MTT assay was performed. IPCs preconditioned with SDF-1 $\alpha$ showed better proliferation $(1.21 \pm 0.041)$ than non-preconditioned IPCs (1.05 \pm $0.027)$ under high $(33 \mathrm{mM} / \mathrm{L})$ glucose concentration (Figure 3c). Our results demonstrated that SDF-1 $\alpha$ preconditioning of IPCs significantly enhanced cell viability as compared to control BMSCs and non-preconditioned IPCs under low as well as high glucose concentrations (Figure 3a) and showed better proliferation under different glucose concentrations (Figure 3c). Previous studies showed that SDF-1 $\alpha$ promotes pancreatic beta-cell survival by the activation of Akt signaling pathway and has cell proliferating, cell survival, anti-apoptotic roles [22], chemotactic properties and facilitates the homing of MSCs in various tissues $[44,45]$.

\section{SDF-1 a preconditioning protects IPCs from glucotoxicity}

These findings were further confirmed by LDH release assay which revealed that preconditioning of IPCs with SDF- $1 \alpha$ extensively lessened the cyto-pathic effects induced by high glucose in vitro (Figure $3 \mathrm{~b}$ ). This indicated that pre-conditioning reduces glucotoxicity caused by high glucose in vitro. Therefore, these results are in accordance with other studies conducted to explore biological effects of SDF- $1 \alpha$ in development of pancreas and in cell based therapies for other organs $[41,44,45]$. Futhur more, pre-conditioning of MSCs with growth factors etc. plays a major role in augmenting resistance of MSCs to stress due to injury or disease in vitro or in vivo [46].

\section{SDF-1 a preconditioned IPCs are glucose responsive}

The pancreatic $\beta$-cells possess the ability to regulate the secretion of insulin in a glucose dependent manner. The glucose-responsive insulin release by SDF- $1 \alpha$ preconditioned IPCs and non-preconditioned IPCs was analyzed in vitro by ELISA after exposing to high glucose. Both BM-derived non-preconditioned IPCs and SDF- $1 \alpha$ pre-conditioned IPCs secreted insulin in response to high glucose challenge in a glucose-regulated manner but SDF- $1 \alpha$ pre-conditioned IPCs distinctly showed higher rate of insulin release $(67.3 \pm 4.9 \mathrm{Vs} 60 \pm 5.4)$ and $(116.6 \pm 5.9$ Vs $85.7 \pm 6.5)$ at 17 and $33 \mathrm{mM} / \mathrm{L}$ glucose concentrations respectively (Figure $3 \mathrm{~d}$ ) indicating that SDF- $1 \alpha$ pre-conditioning had positive impact on the 

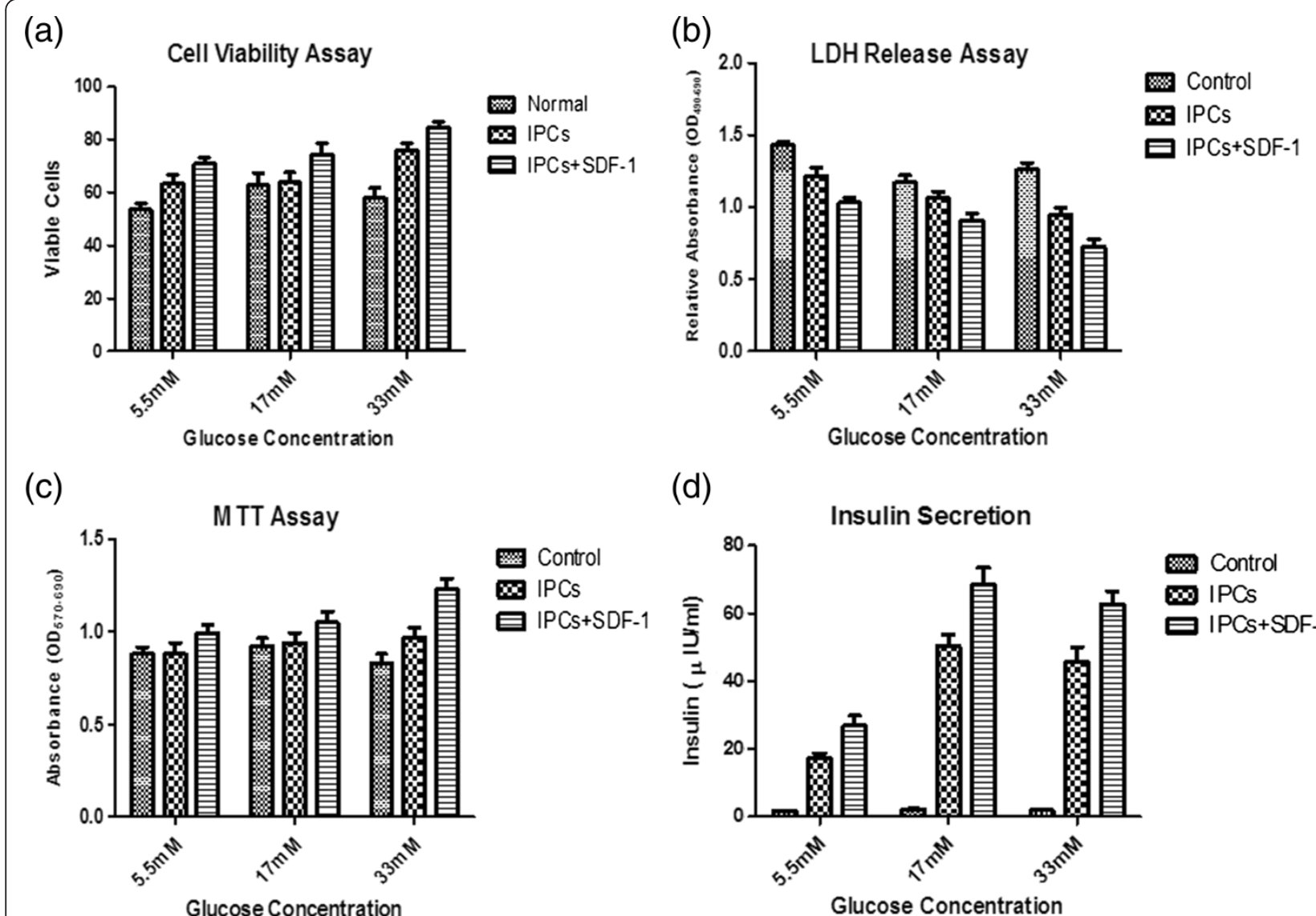

(d)

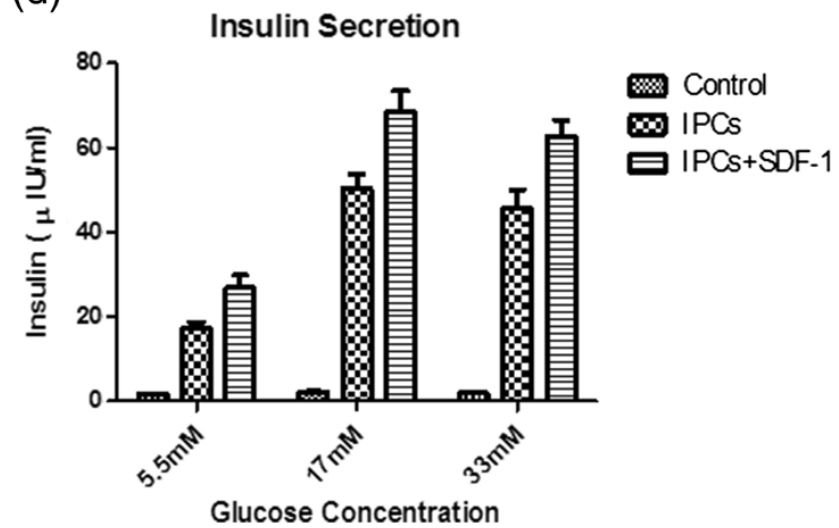

Figure 3 Effect of SDF-1a preconditioning on IPCs under different glucose concentrations in vitro. a) The number of viable cells is plotted in relevance with normal BM-derived MSCs. There is a marked increase in cell survivability in pre-conditioned group than control and non preconditioned groups $(n=6)$. b) Cyto-protective effect of SDF-1a pre-conditioning on IPCs. Pre-conditioned IPCs showed low level of LDH compared to the control and non pre-conditioned groups indicating less cellular injury. c) Effect of SDF-1a pre-conditioning on cell proliferation under different glucose concentrations. Pre-conditioned IPCs showed higher rate of proliferation as compared to the control and non preconditioned groups. d) Glucose responsive insulin release by SDF-1a pre-conditioned IPCs. The IPCs were exposed to either $5.5 \mathrm{mM} / \mathrm{L}$, $17 \mathrm{mM} / \mathrm{L}$ or $33 \mathrm{mM} / \mathrm{L}$ glucose. Insulin released from the IPCs upon glucose induction was determined by ELISA. The experiments were performed in triplicates and repeated three times. All values were expressed as mean \pm SEM.

glucose dependent insulin release. Control BMSCs cultured in normal medium showed no significant release of insulin in different glucose concentrations.

\section{In vivo studies}

\section{Reversal of hyperglycemia in STZ-induced diabetic rats}

To observe the role of SDF- $1 \alpha$ pre-conditioning on IPCs in vivo, $3 \times 10^{6} \mathrm{SDF}-1 \alpha$ pre-conditioned IPCs were transplanted in left kidney capsule of the STZ-induced diabetic rats $(\mathrm{n}=8)$. The control group $(\mathrm{n}=8)$ was injected with serum free medium only. The blood glucose level of transplanted rats was monitored for 28 days after transplantation. The results showed that the glucose levels in the rats transplanted with SDF- $1 \alpha$ preconditioned IPCs $(173 \pm 10.4 \mathrm{mg} / \mathrm{dl})$ decreased significantly (Figure 4a) as compared to diabetic control group $(482 \pm 26.8 \mathrm{mg} / \mathrm{dl})$. The decrease in glucose levels in transplanted group was significant. The control diabetic rats remained hyperglycemic throughout the study period.

Increase in serum insulin levels of transplanted diabetic rats The functionality of SDF- $1 \alpha$ pre-conditioned IPCs in vivo was assessed by serum insulin level measurement by ELISA. The results demonstrated that the insulin levels in the SDF- $1 \alpha$ pre-conditioned IPCs group was increased from $(0.317 \pm 0.01)$ at day 10 to $(0.47 \pm 0.024)$ at day 20 . This increase was significant as compared to diabetic control group $(0.032 \pm 0.009)$ at day 10 and $(0.027 \pm 0.024)$ at day 20 (Figure $4 \mathrm{~b}$ ).

\section{SDF-1 a preconditioning enhances homing of IPCs in diabetic kidney}

The homing of transplanted IPCs was assessed by tracking PKH-26 labeled IPCs in left kidney, the site of 

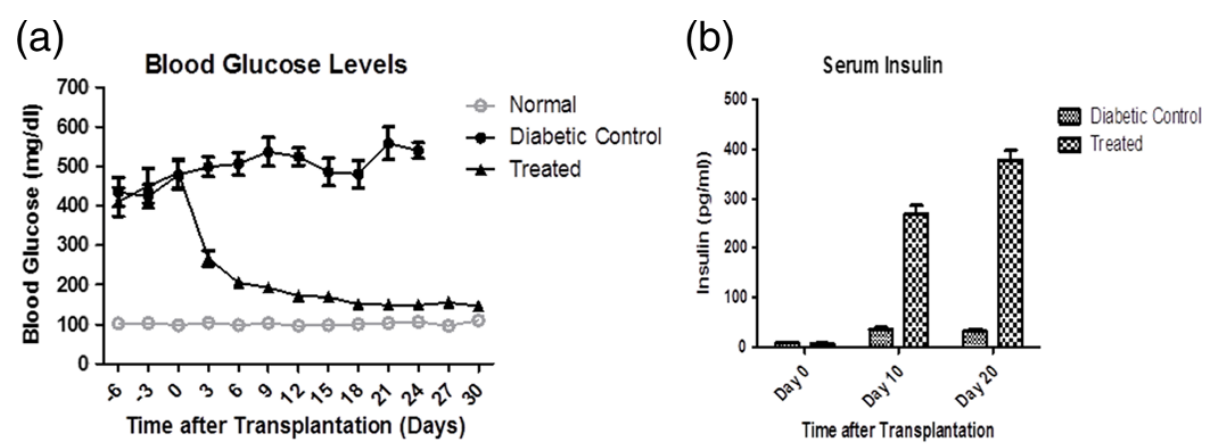

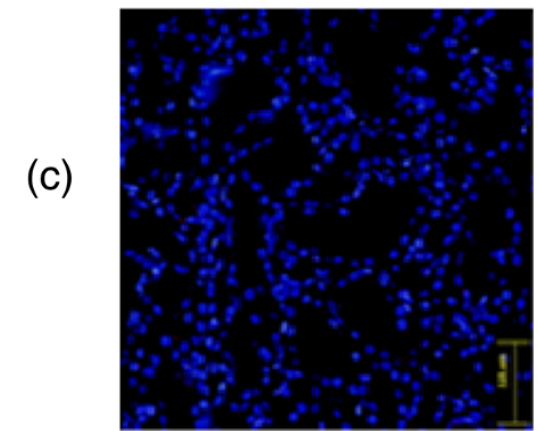

Control

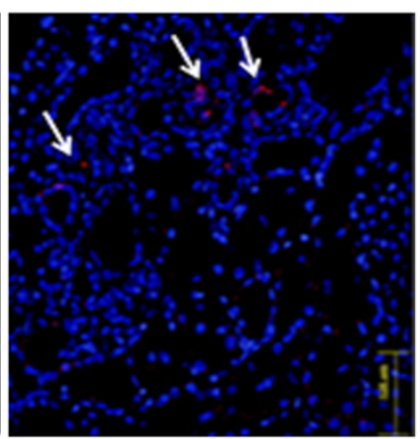

Transplanted

Figure 4 Functional analysis after SDF-1a preconditioned IPCs transplantation in vivo. a) Blood glucose levels after SDF-1a Preconditioned IPCs transplantation. Glucose levels were monitored by tail-vein blood at under random conditions. b) Serum Insulin Levels after Transplantation of SDF-1a Pre-conditioned IPCs. The serum insulin measured by ELISA of serum samples at days mentioned. The day 0 indicates the day of cell transplantation. All values are expressed as mean \pm SEM. c) Homing of transplanted SDF-1a Pre-conditioned IPCS in left Kidney at $d$ 10 in control diabetic rats and SDF-1a preconditioned IPCs transplanted rats.

transplantation. The results showed several PKH-26 labeled IPCs in the sections of left kidneys of recipient rats (Figure 4c).

\section{Ki-67 staining for the determination of proliferating cells}

The Ki-67 staining of pancreatic sections of rats transplanted with SDF-1 $\alpha$ pre-conditioned IPCs revealed many $\mathrm{Ki}-67$ positive cells in pancreas. There were no Ki-67 positive cells in the pancreatic sections of control diabetic rats which received only serum free medium (Figure 5). This confirms the presence of proliferating cells in rats transplanted with SDF- $1 \alpha$ preconditioned IPCs.

\section{Conclusions}

Therapeutic potential of stem cells has made stem cell research one of the most promising fields in biomedical research. There is a growing concern to find alternative sources of $\beta$-cells to cure diabetes. MSCs have emerged as a new cell therapeutic tool in regenerative medicine. We in this study with slight difference from many others

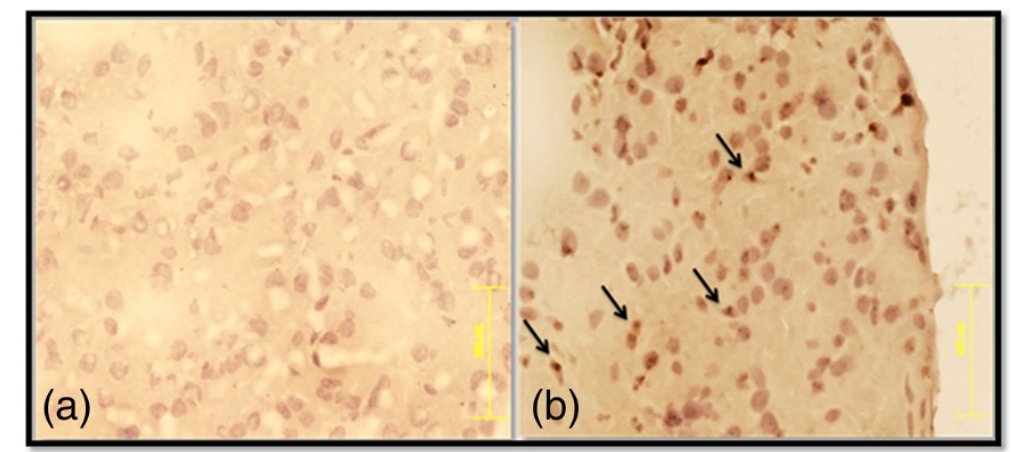

Figure 5 The Ki-67 staining of pancreatic sections of rats transplanted with SDF-1a preconditioned IPCs. Proliferating cells stained with Ki-67 in pancreas after transplantation of SDF-1 a preconditioned IPCs in control diabetic rats (a) and SDF-1a preconditioned IPCs transplanted rats (b). 
[9,31-33] reported that BMSCs can be differentiated into IPCs but this study demonstrated for the first time the effect of SDF- $1 \alpha$ pre-conditioning on IPCs in vitro as well as in vivo. SDF-1 $\alpha$ enhances their survival and proliferation, lowers apoptosis in vitro and reverses STZ-induced diabetes in rats. The results demonstrated that the insulin secreted by SDF-1 $\alpha$ pre-conditioned IPCs after induction with high glucose was glucose responsive. In vivo study demonstrated reversal of hyperglycemia and an increase in serum insulin levels in the rats transplanted with SDF- $1 \alpha$ pre-conditioned IPCs.

\section{Abbreviations}

MSCs: Mesenchymal stem cells; IPCs: Insulin producing cells; SDF-1a: Stromal cell derived factor-1alpha; DM: Diabetes mellitus; BMSCs: Bone marrow derived mesenchymal stem cells; PDX-1: Pancreatic and duodenal homeobox-1; GLP-1: Glucagon-like peptide-1; SD: Sprague-Dawley; EGF: Epidermal growth factor; DTZ: Dithizone; STZ: Streptozotocin LDH: Lactate dehydrogenase; KRBH: Krebs Ringer bicarbonate HEPES.

\section{Competing interests}

All authors confirmed that, "no competing interests exist".

\section{Authors' contributions}

MT conceived the idea, participated in the design of study, performed culturing and in vitro treatments, participated in in vivo experiments, executed statistical analysis and drafted the paper. MSM participated in transplantation and surgical procedures. AM analyzed the in vitro data and helped to draft the manuscript. SNK participated in study design and proofreading the manuscript and SR contributed in study design, funding and final approval of the manuscript. All authors read and approved the final manuscript.

\section{Acknowledgement}

This work was supported by Higher Education Commission Islamabad, Pakistan. The authors thank to Dr. Muhammad Ashraf for his technical assistance.

\section{Author details}

'National Centre of Excellence in Molecular Biology, University of the Punjab, Lahore, Pakistan. ${ }^{2}$ Current Affiliation: Department of Biotechnology, Mirpur University of Science and Technology, Mirpur, AK, Pakistan. ${ }^{3}$ Current Affiliation: Department of Bioinformatics and Biotechnology, Government College University, Faisalabad 38000, Pakistan.

Received: 17 January 2013 Accepted: 2 May 2013

Published: 6 May 2013

\section{References}

1. Gepts W: Islet morphology in type 1 diabetes. Behring Inst Mitt 1984, 75:39-41.

2. Shaw JE, Sicree RA, Zimment: Global estimates of the prevalence of diabetes for 2110 and 2030. Diabetes Res Clin Pract 2010, 87:4-14.

3. Robertson RP, Davis C, Larsen J, Stratta R, Sutherland DE: Pancreas and islet transplantation in type 1 diabetes. Diabetes Care 2006, 29(4):935.

4. Marzorati S, Pileggi A, Ricordi C: Allogeneic islet transplantation. Expert Opin Biol Ther 2007, 7(11):1627-1645.

5. Bianco P, Kuznetsov SA, Riminucci M, Gehron RP: Postnatal skeletal stem cells. Methods Enzymol 2006, 419:117-148.

6. Volarevic V, Arsenijevic N, Lukic ML, Stojkovic M: Concise review: Mesenchymal stem cell treatment of the complications of diabetes. Stem Cells 2011, 29(1):5-10.

7. Volarevic V, Al-Qahtani A, Arsenijevic N, Pajovic S, Lukic ML: Interleukin-1 receptor antagonist (IL-1Ra) and IL-1Ra producing mesenchymal stem cells as modulators of diabetogenesis. Autoimmunity 2010, 43:255-263.

8. Xie QP, Huang H, Xu B, Dong X, Gao SL, Zhang B, Wu YL: Human bone marrow mesenchymal stem cells differentiate into insulin-producing cells upon microenvironmental manipulation in vitro. Differentiation 2009, 77:483-491.
9. Sun Y, Chen L, Hou XG, Hou WK, Dong JJ, Sun L, Tang KX, Wang B, Song J, $L i H$, Wang KX: Differentiation of bone marrow-derived mesenchymal stem cells from diabetic patients into insulin-producing cells in vitro. Chin Med J 2007, 120:771-776.

10. Moriscot C, de Fraipont F, Richard MJ, Marchand M, Savatier P, Bosco D, Favrot M, Benhamou PY: Human bone marrow mesenchymal stem cells can express insulin and key transcription factors of the endocrine pancreas developmental pathway upon genetic and/or microenvironmental manipulation in vitro. Stem Cells 2005, 23(4):594-603.

11. Zanini C, Bruno S, Mandili G, Baci D, Cerutti F, Cenacchi G, Izzi L, Camussi G, Forni M: Differentiation of mesenchymal stem cells derived from pancreatic islets and bone marrow into islet-like cell phenotype. PLoS One 2011, 6(12):e28175.

12. Chen $L B$, Jiang $X B$, Yang $L$ : Differentiation of rat marrow mesenchymal stem cells into pancreatic islet beta-cells. World J Gastroenterol 2004, 10(20):3016-3020.

13. Tolar J, Nauta AJ, Osborn MJ, Panoskaltsis Mortari A, McElmurry RT, Bell S, Xia L, Zhou N, Riddle M, Schroeder TM, Westendorf JJ, Mclvor RS, Hogendoorn PC, Szuhai K, Oseth L, Hirsch B, Yant SR, Kay MA, Peister A, Prockop DJ, Fibbe WE, Blazar BR: Sarcoma derived from cultured mesenchymal stem cells. Stem Cells 2007, 25:371-379.

14. Le Blanc K, Pittenger M: Mesenchymal stem cells: Progress toward promise. Cytotherapy 2005, 7:36-45.

15. Atsma DE, Fibbe WE, Rabelink TJ: Opportunities and challenges for mesenchymal stem cell-mediated heart repair. Curr Opin Lipidol 2007, 18:645-649.

16. Moller DE: New drug targets for type 2 diabetes and the metabolic syndrome. Nature 2001, 414:821-827.

17. Micallef SJ, Janes ME, Knezevic K, Davis RP, Elefanty AG, Stanley EG: Retinoic acid induces Pdx1-positive endoderm in differentiating mouse embryonic stem cells. Diabetes 2005, 54:301-305.

18. Shi Y, Hou L, Tang F, Jiang $W$, Wang $P$, Ding $M$, Deng H: Inducing embryonic stem cells to differentiate into pancreatic beta cells by a novel three-step approach with activin A and all-trans retinoic acid. Stem Cells 2005, 23(5):656-662.

19. Otonkoski T, Beattie GM, Mally MI, Ricordi C, Hayek A: Nicotinamide is a potent inducer of endocrine differentiation in cultured human fetal pancreatic cells. J Clin Invest 1993, 92(3):1459-1466.

20. Edlund $\mathrm{H}$ : Pancreatic organogenesis-developmental mechanisms and implications for therapy. Nat Rev Genet 2002, 3:524-532.

21. Egan JM, Bulotta A, Hui H, Perfetti R: GLP-1 receptor agonists are growth and differentiation factors for pancreatic islet beta cells. Diabetes Metab Res Rev 2003, 19:115-123.

22. Yano N, Suzuki D, Endoh M, Zhao CT, Padbury JF, Tseng YT: A novel phosphoinositide 3-kinase-dependent pathway for angiotensin II/AT-1 receptor-mediated induction of collagen synthesis in MES-13 mesangial cells. J Biol Chem 2007, 282:18819.

23. Peng $H$, Huang $Y$, Rose J, Erichsen D, Herek S, Fujii N, Tamamura $H_{\text {, }}$ Zheng J: Stromal cell-derived factor 1-mediated CXCR4 signaling in rat and human cortical neural progenitor cells. J Neurosci Res 2004, 76(1):35-50.

24. Kayali AG, Van Gunst K, Campbell IL, Stotland A, Kritzik M, Liu G, FlodstromTullberg M, Zhang YQ, Sarvetnick N: The stromal cell-derived factor1alpha/CXCR4 ligand-receptor axis is critical for progenitor survival and migration in the pancreas. J Cell Biol 2003, 163:859-869.

25. Yao R, Cooper GM: Requirement for phosphatidylinosotol- 3 kinase in the prevention of apoptosis by nerve growth factor. Science 1995, 267:2003-2006.

26. Datta SR, Brunet A, Greenberg ME: Cellular survival: a play in three Akts. Genes Dev 1999, 13:2905-2927.

27. Jetton TL, Lausier J, LaRock K, Trotman WE, Larmie B, Habibovic A Peshavaria M, Leahy JL: Mechanisms of compensatory beta-cell growth in insulin-resistant rats: roles of Akt kinase. Diabetes 2005, 54(8):2294-2304.

28. Watanabe $H$, Saito $H$, Rychahou PG, Uchida T, Evers BM: Aging is associated with decreased pancreatic acinar cell regeneration and phosphatidylinositol 3 kinase/Aktactivation. Gastroenterology 2005, 128:1391-1404

29. Rakienten N, Rakienten ML, Nadkarni MV: Studies on the diabetogenic action of streptozotocin. Cancer Chemotheraphy Reports 1963, 29:91-98.

30. Pasha Z, Wang Y, Sheikh R, Zhang Z, Zhao T, Ashraf M: Preconditioning enhances cell survival and differentiation of stem cells during transplantation in infarcted myocardium. Cardiovasc Res 2008, 77:134-142. 
31. Wu XH, Liu CP, Xu KF, Mao XD, Zhu J, Jiang JJ, Cui D, Zhang M, Xu Y, Liu C: Reversal of hyperglycemia in diabetic rats by portal vein transplantation of islet-like cells generated from bone marrow mesenchymal stem cells. World J Gastroenterol 2007, 13(24):3342-3349.

32. Tang DQ, Cao LZ, Burkhardt BR, Xia CQ, Litherland SA, Atkinson MA, Yang $\mathrm{MJ}$ : In vivo and in vitro characterization of insulin-producing cells obtained from murine bone marrow. Diabetes 2004, 53:1721-1732.

33. Li L, Yi M, Seno M, Kojima I: Activin A and betacellulin: effect on regeneration of pancreatic beta-cells in neonatal streptozotocin-treated rats. Diabetes 2004, 53:608-615

34. Suzuki A, Nakauchi H, Taniguchi H: Glucagon-like peptide 1 (1-37) converts intestinal epithelial cells into insulin-producing cells. Proc Natl Acad Sci USA 2003, 100(9):5034-5039.

35. Tayaramma T, Ma B, Rohde M, Mayer H: Chromatin remodeling factors allow differentiation of bone marrow cells into insulin-producing cells. Stem Cells 2006, 24:2858-2867.

36. Neshati Z, Matin MM, Bahrami AR, Moghimi A: Differentiation of mesenchymal stem cells to insulin-producing cells and their impact on type 1 diabetic rats. J Physiol Biochem 2010, 66(2):181-187.

37. Chakrabarti SK, Mirmira RG: Transcription factors direct the development and function of pancreatic $\beta$ cells. Trends Endocrinol Metab 2003, 2:78-84

38. Sumi S, Gu Y, Hiura A, Inoue K: Stem cells and regenerative medicine for diabetes mellitus. Pancreas 2004, 29:e85-e89.

39. Henseleit KD, Nelson SB, Kuhlbrodt K, Hennings JC, Ericson J, Sander M: NKX6 transcription factor activity is required for $\beta$ - and $\beta$-cell development in the pancreas. Development 2005, 132:3139-3149.

40. Oliver-Krasinski JM, Stoffers DA: On the origin of the $\beta$-cell. Genes Dev 2008, 22:1998-2021

41. Habener JF, Kemp DM, Thomas MK: Minireview: transcriptional regulation in pancreatic development. Endocrinology 2005, 146:1025-1034.

42. Kume S: Stem-cell-based approaches for regenerative medicine. Dev Growth Differ 2005, 47(6):393-402.

43. Gradwohl G, Dierich A, LeMeur M, Guillemot F: Neurogenin3 is required for the development of the four endocrine cell lineages of the pancreas. Proc Natl Acad Sci USA 2000, 97:1607-1611.

44. Tang J, Wang J, Yang J, Kong X, Zheng F, Guo L, Zhang L, Huang Y: Mesenchymal stem cells over-expressing SDF-1 promote angiogenesis and improve heart function in experimental myocardial infarction in rats. Eur J Cardiothorac Surg 2009, 36:644-650

45. Petit I, Jin D, Rafii S: The SDF-1-CXCR4 signaling pathway: a molecular hub modulating neo-angiogenesis. Trends Immunol 2007, 28:299-307.

46. Masoud MS, Anwar SS, Afzal MZ, Mehmood A, Khan SN, Riazuddin S: Preconditioned mesenchymal stem cells ameliorate renal ischemic injury in rats by augmented survival and engraftment. J Trans/ Med 2012, 5(10):243.

\section{doi:10.1186/1479-5876-11-115}

Cite this article as: Tariq et al.: Stromal cell derived factor-1alpha protects stem cell derived insulin-producing cells from glucotoxicity under high glucose conditions in-vitro and ameliorates drug induced diabetes in rats. Journal of Translational Medicine 2013 11:115.

\section{Submit your next manuscript to BioMed Central and take full advantage of:}

- Convenient online submission

- Thorough peer review

- No space constraints or color figure charges

- Immediate publication on acceptance

- Inclusion in PubMed, CAS, Scopus and Google Scholar

- Research which is freely available for redistribution 